\title{
Commentary: U-CIRP-ing the neurological effects of deep hypothermic circulatory arrest
}

\author{
Robert Sorabella, MD, ${ }^{a}$ and Ming-Sing Si, $\mathrm{MD}^{\mathrm{b}}$ \\ From the a Division of Cardiothoracic Surgery, Department of Surgery, University of Alabama at Birmingham, \\ Birmingham, Ala; and ${ }^{\mathrm{b}}$ Section of Pediatric Cardiovascular Surgery, Department of Cardiac Surgery, Univer- \\ sity of Michigan, Ann Arbor, Mich. \\ Disclosures: Authors have nothing to disclose with regard to commercial support. \\ Received for publication Aug 12, 2019; revisions received Aug 12, 2019; accepted for publication Aug 12, 2019; \\ available ahead of print Oct 18, 2019. \\ Address for reprints: Ming-Sing Si, MD, 11-735 C.S. Mott Children's Hospital SPC 4204, 1540 E Hospital Drive, \\ Ann Arbor, MI 48109-4204 (E-mail: mingsing@umich.edu). \\ J Thorac Cardiovasc Surg 2020;159:2449-50 \\ $0022-5223 / \$ 36.00$ \\ Copyright (C) 2019 by The American Association for Thoracic Surgery \\ https://doi.org/10.1016/j.jtcvs.2019.08.076
}

Deep hypothermia is a form of protection for the brain and other organs when the circulation, and therefore oxygen delivery, must be ceased to achieve a bloodless field to perform reconstruction of the aortic arch or other cardiac defects. Although this strategy is commonly used and indispensable in pediatric and adult cardiac surgical procedures, it does have some adverse effects that lead to neurological injury. ${ }^{1,2}$ Neuroinflammation appears to be associated with deep hypothermic circulatory arrest (DHCA)-induced injury, however the details of how this occurs and if this is a causative or secondary process are unknown. ${ }^{3,4}$

In this issue of The Journal of Thoracic and Cardiovascular Surgery, Liu and colleagues present an exciting study that defines the role of cold-inducible RNA-binding protein (CIRP) in neuroinflammation and neuronal injury that occurs after DHCA. ${ }^{5}$ These investigators used novel CIRP deficient rats and a remarkable experimental model of cardiopulmonary bypass in rats to evaluate the role of CIRP in DHCA. They also performed in vitro experiments with a microglial cell line and conditions to mimic DHCA to evaluate the function of CIRP and its downstream mediators. These investigators reported an increase in CIRP expression in response to a period of circulatory arrest as well as decreased histologic injury and microglial activation in a CIRP deficient rat after a similar period of DHCA. The group then proceeded with in vitro studies using murine microglial cells to show that targeting CIRP with specific small interference RNA followed by a period of oxygen/ glucose deprivation resulted in less proinflammatory cytokine production and cell death. On the basis of differential gene regulation analysis, it appears that CIRP might play a role in activating the NF-kB inflammatory pathway, which might provide a novel therapeutic target for future consideration.

This study is remarkable because of its rigorous design as well as the use of novel transgenic rats and experimental

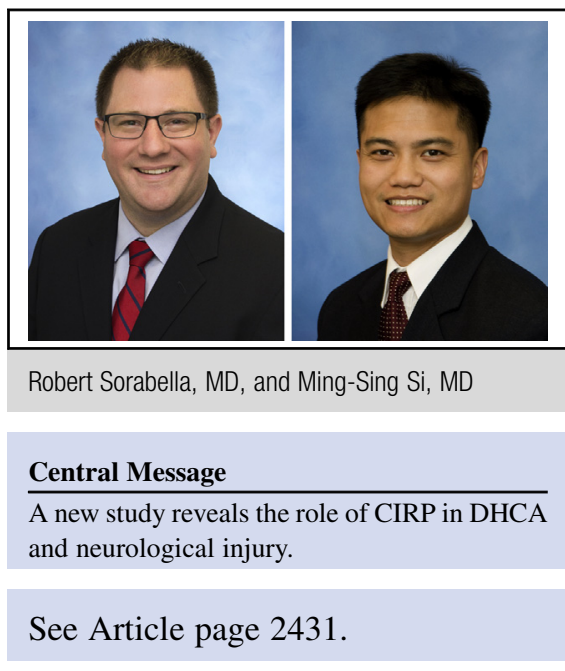

model of bypass. The function of CIRP has been recently recognized in other scenarios of pathological inflammation such as hemorrhagic shock and sepsis, ${ }^{6}$ and thus the findings of this study could have a broad effect in other clinical conditions.

However, the results of these findings seem to be at odds with the work of Sakurai and colleagues, ${ }^{7}$ who reported that moderate hypothermia stimulated the transcription of CIRP in murine fibroblasts, which suppressed TNF-induced apoptosis. However, this study was performed with fibroblasts (not neuronal cells) and the condition of ischemia was not included. Therefore, CIRP might have contextand cell type-dependent functions, underlying the importance of faithfully replicating the conditions of DHCA in the experimental setting.

Using the single-cell sequencing database from the Tabula Muris project, ${ }^{8}$ we found that CIRP transcripts are present in all cell types of the murine brain. It is not known if global or specific lineage expression of CIRP is responsible for the untoward effects of DHCA and it would therefore be important to evaluate this specifically with inducible, lineage-restricted knockout animals.

\section{References}

1. Algra SO, Jansen NJ, van der Tweel I, Schouten AN, Groenendaal F, Toet M, et al Neurological injury after neonatal cardiac surgery: a randomized, controlled trial of 2 perfusion techniques. Circulation. 2014;129:224-33.

2. Beca J, Gunn JK, Coleman L, Hope A, Reed PW, Hunt RW, et al. New white matter brain injury after infant heart surgery is associated with diagnostic group and the use of circulatory arrest. Circulation. 2013;127:971-9. 
3. Algra SO, Groeneveld KM, Schadenberg AW, Haas F, Evens FC, Meerding J, et al. Cerebral ischemia initiates an immediate innate immune response in neonates during cardiac surgery. J Neuroinflammation. 2013;10:24.

4. Tu LN, Timms AE, Kibiryeva N, Bittel D, Pastuszko A, Nigam V, et al. Transcriptome profiling reveals activation of inflammation and apoptosis in the neonatal striatum after deep hypothermic circulatory arrest. J Thorac Cardiovasc Surg. 2019;158:882-90.e4

5. Liu M, Li Y, Gao S, Yan S, Zhang Q, Liu G, et al. A novel target to reduce microglial inflammation and neuronal damage after deep hypothermic circulatory arrest. J Thorac Cardiovasc Surg. 2020;159:2431-44.e7.
6. Qiang X, Yang WL, Wu R, Zhou M, Jacob A, Dong W, et al. Cold-inducible RNAbinding protein (CIRP) triggers inflammatory responses in hemorrhagic shock and sepsis. Nat Med. 2013;19:1489-95.

7. Sakurai T, Itoh $\mathrm{K}$, Higashitsuji $\mathrm{H}$, Nonoguchi $\mathrm{K}$, Liu $\mathrm{Y}$, Watanabe $\mathrm{H}$, et al. CIRP protects against tumor necrosis factor-alpha-induced apoptosis via activation of extracellular signal-regulated kinase. Biochim Biophys Acta. 2006;1763:290-5.

8. Tabula Muris Consortium, Overall coordination, Logistical coordination, Organ collection and processing, Library preparation and sequencing, Computational data analysis, et al. Single-cell transcriptomics of 20 mouse organs creates a Tabula Muris. Nature. 2018;562:367-72. 